\title{
FinTech Start-Ups Financing in Islamic Banks in Oman: Qualitative Evidence
}

\author{
Abdelghani Echchabi ${ }^{1, *}$ Mohammed Omar ${ }^{2}$ Abdullah Ayedh ${ }^{3}$ Welcome Sibanda \\ ${ }^{1}$ Business Division, Dubai Men's Campus, Higher Colleges of Technology, Dubai, United Arab Emirates \\ ${ }^{2}$ College of Business Administration, A'Sharqiyah University, Ibra, Oman Author \\ ${ }^{3}$ Faculty of Economics and Muamalat, Universiti Sains Islam Malaysia, Nilai, Malaysia \\ *Corresponding author. Email:abdelghani.mo@gmail.com
}

\begin{abstract}
The objective of the study was mainly to shed light on the current state and future prospects of FinTech in Oman, with particular focus on its potential contribution to the Islamic finance industry. The study used qualitative methods in forms of in-depth interviews with eight Islamic banks' managers in Oman. The findings revealed that the FinTech industry in Oman is still operating under-potential. This might be due to the general lack of interest in this area by the Omani startup businesses. This situation might also be due to the lack of financing opportunities by local financial institutions, including both Islamic and conventional financial institutions. The findings also showed that the start-ups in Oman prefer long term financial schemes, while the Islamic financial institutions (IFIs) generally prefer short term financing on Musharakah and Ijarah contracts. Finally, the findings showed that the IFIs are optimistic regarding the prospects of growth and success of FinTech in Oman. It is noteworthy that this is one of the early studies that address the FinTech startups financing from an Islamic perspective, and hence lays the ground for the future studies to be conducted in this area.
\end{abstract}

Keywords: Oman, FinTech, Financing, Islamic Bank.

\section{INTRODUCTION}

The financial industry has witnessed a great transformation since the introduction of various technological tools to improve the way the financial services are operated and offered [1]. These tools have been formally grouped under the title "FinTech", and broadly defined as technology application in the finance field [2]. FinTech provides a practical solution, an easy access, comfort and convenience, and cost effectiveness of financial services to both financial services providers and customers [3]. These qualities -among otherscontribute in reducing the reliance on traditional establishments and incite customers to gradually shift toward these alternative services [4].

This wave of FinTech tools developments was marked by the establishment of a significant number of FinTech start-ups in many countries. This emergence of FinTech start-ups has either been disruptive or collaborative, depending on country's economy and the financial market structure and composition. In this regard, a good understanding of the current state and future potential of FinTech start-ups would result in great benefits for the financial institutions, the FinTech startups themselves, as well as the economy as a whole [5]. This is particularly valid in the case of IFIs that still have a major role to play in the economic and financial growth in a country like Oman, which is actively and continuously looking for alternative sources of income and economic growth drivers that are in line with their religious affiliations, and away from the crude oil income [6]. However, FinTech businesses can also be disruptive to the traditional financial institutions in cases where the latter are not able to provide the services expected by the customers that are alternatively provided by FinTech start-ups [7] [8]. This is the case of peer to peer lending for instance where many start-ups are lending considerable amounts of money and receiving customers' deposits on online platforms, with relatively more lenient requirements and procedures compared to traditional financial firms. This is also the case of 'unbanked' or 'under-banked' segments such as small businesses and the small loan market that do not generate enough income to support their request for funds from the traditional banking industry [9]. This indicates that successfully introducing complementary financial services like FinTech, provides a better chance to reach unbanked or under-banked customers. This form of financial inclusion certainly has a major positive impact on economic development and growth [10]. Furthermore, it has the potential to revolutionize global finance by making it more decentralized and egalitarian [11]. In addition, the implementation of FinTech tools by banking and financial institutions at various levels significantly 
contributes to the overall efficiency, productivity and growth of these institutions [5] [12].

This is even more relevant in the case of IFIs. According to [13], the IFIs have been witnessing a rapid growth in the recent years. However, IFIs hindered by conventional banks competition remain far behind. Gillet argued that IFIs could use FinTech as a tool to set them forward to play a significant role in providing Islamic FinTech services to the unbanked or under-banked Muslim customers.

Nevertheless, there are some conditions that have to be met to ensure the efficient and successful implementation of these services. For instance, [14] found that the countries that witness the highest levels of FinTech businesses start-ups are characterized by the availability of the latest updated technologies, a welldeveloped capital markets, and high rates of mobile telephone subscriptions. In addition, the availability of qualified labour force was also found to have a direct positive impact on this sector.

In this regard, [15] stated that the Middle East and North Africa (MENA) and particularly the Gulf Cooperation Council (GCC) witnessed a tremendous growth in the FinTech sector. Specifically, the UAE lunched FinTech Hive programme to facilitate and accelerate the FinTech and Islamic FinTech. In addition, Abu Dhabi Global Market (ADGM) and Bahrain lunched their regulatory Sandbox to foster innovation of FinTech start-ups. More importantly, according to [16], the number of FinTech start-ups across the MENA region is expected to be 250 in 2020 compared to 105 in 2015.

As such, the objective of the study is to shed light on the current status of FinTech start-ups in Oman and the financing opportunities offered to them by IFIs. More importantly, the study attempts to explore the conditions and requirements imposed by these institutions to approve Islamic financing to these start-ups. Finally, the study discusses the future prospects of FinTech applications in Oman, and their potential contribution to the development and growth of IFIs in terms of technology and income. Indeed, IFIs offering Shari'ahcompliant financial services (financial services that are in line with the Islamic law) need a dedicated end-to-end Islamic banking system that facilitates and automates Shari'ah-compliant banking operations and enables banks to scale up their operations to meet global competition, grow market share, retain the loyalty of their customers and of more importance, enhance their profitability [17]. It is noteworthy that achieving these objectives also reflects the contribution of FinTech startups to the Islamic finance industry in terms of income and technology development.

It is worth stressing that the systematic academic research on the topic of Fin $\neg$ Tech is still in its infancy, typically focuses on one is $\neg$ sue and lacks a robust theoretical and empirical base [18]. Hence, this study enriches the literature on FinTech development and growth especially in the Islamic finance area.

\section{LITERATURE REVIEW}

According to Frame, [19] there are two significant drivers of innovation in finance, namely technology and regulation. Particularly, the increased complexity and variety in transactions and regulatory demands, costly papermill procedures, and inefficient information distribution across databases may all facilitate demand for FinTech innovation. Specifically, FinTech as an emerging technology platform allowed many nonfinancial institutions to provide financial services at both business and retail levels [20].

There are currently well-defined FinTech tools that are widely used by various companies. Specifically, digital banking has become a requirement for modern business operations, allowing customers to make payments, and transfer money both internally and internationally without needing to turn to banks. These services are performed in cost-effective and faster way, compared to the traditional bank services that are no longer appealing and beneficial to customers. [21] have argued that traditional financial services are rapidly becoming outdated and no more adequate to serve customers' needs, especially in international transactions.

Digital lending is one of the manifestations of FinTech which is considered a shift in the lending paradigm based on FinTech systems development [20]. This includes peer to peer (P2P) lending, crowdfunding, etc. P2P lending allows individuals and businesses to exchange funds directly among each other, while crowdfunding involves three parties, namely, "the entrepreneur who needs funding, the contributors who may be interested in supporting the cause or project, and the moderating organization that facilitates the engagement between the contributors and the initiator" [22]. Using these modes among others allows start-ups to obtain financing which has been rather difficult from traditional financial institutions and markets. Moreover, implementing these tools effectively lowers the transaction costs for start-ups compared to the lending arrangements with financial intermediaries and reduces financial frictions [21]. According to [18], the digital lending tools are still nascent in the MENA region due to the highly regulated financial systems, but it is slowly gaining acceptance across the region.

Investment is another area covered by FinTech solutions allowing customers to manage and hold their existing assets in a single space. With such platforms, investors and traders are able to connect with each other to exchange financial knowledge and recommendations, trade real commodities, foreign currencies and financial 
securities, and monitor risks involved in various transactions [22].

FinTech has also provided personal finance solutions in form of automated wealth management system, commonly known as robot adviser, that provides financial advice to customers against a low fee compared to real-life advisors. These robot advisors suggest investment portfolios based on customers' investment preferences and characteristics, using advanced algorithms [22].

In its attempt to reach the underserved customers and enhance the insurance services offered by traditional insurance firms, FinTech start-ups started offering alternative insurance services in form of InsurTech. These services enable a more direct relationship between the insurer and the customer by using advanced data analytics of risks and claims [22].

In the specific case of Islamic FinTech solutions, Interestingly, some alternatives are attempting to bring Shari'ah compliant products to the FinTech market, such as the investment advisor Finerd [18] or the various forms of crowdfunding based on Shari'ah compliant structures like Mudharabah (equity financing) [23].

Regulation could be another challenge facing not only start-ups, but also traditional financial institutions, as any change regulations significantly affects these institutions' business [7] [24]. However, the financial products offered by FinTech businesses operating under shadow banking might not comply with existing applicable financial regulations [20]. As a result, startups need to be prepared to handle potential risk resulting from the uncertainty of new regulations applicable to FinTech arrangements [20]. As such, [2] noted that significant regulatory changes are required for FinTech not only to improve financial stability and easy access to financial services, but also to protect the rights of FinTech start-ups and customers.

Another challenge which is probably the most important is the security and safety [25]. In this regard, FinTech start-ups are required to maintain security and privacy as one of their top priorities, as these services are offered in a highly susceptible environment where a huge amount of sensitive data is continuously exchanged [22].

These challenges and potential issues make up a general image of FinTech start-ups and contribute significantly in forming a perception about their operating systems, services they provide etc. especially from potential customers and fund providers. Particularly the high level of risk/uncertainty associated with them, makes it generally difficult for them to obtain financing from various sources, and this situation has even worsened after the 2008 global financial crisis and its repercussions [26].

\section{METHODOLOGY}

The study applies the qualitative methodology in the form of semi-structured in-depth interviews with managers of Islamic banks and Islamic banking windows in different regions of Oman. This approach allows the researcher to collect comprehensive and detailed information of FinTech experience among Islamic banks' managers in Oman [27] [28].

Since the empirical studies on FinTech are still scarce, especially with relation to the Islamic finance area, the current study adopts an exploratory design of qualitative methods, which is in accordance with similar studies [18]. The study initially focused on five main themes that were subsequently developed during interviews, namely, (1) the current status of Islamic financing for FinTech start-ups in Oman, (2) the financing schemes and arrangements offered to FinTech start-ups by IFIs, (3) the FinTech start-ups Islamic financing preferences, (4) the requirements imposed by IFIs for financing FinTech start-ups, and (5) the potential future contribution of FinTech to the Islamic finance industry in Oman.

The selection of the interviewees is based on their experience in the Islamic banking field, as well as their decision-making power within their banks. As such branch managers of Islamic banks in different regions were selected. In this regard, two representatives were selected from each major Islamic bank/Islamic banking window. Hence, a total of 5 interviewees were confirmed after a two-stage selection process. [29] suggested that not more than ten interviewees should be included in the study, to allow an in-depth exploration and collection of information.

It is noteworthy that a phenomenological approach to data analysis was adopted. This involves the interpretation and reflection on the data transcript to achieve a holistic understanding of the meaning of the participants' experiences [30].

\section{RESULT}

\section{Financing of FinTech start-ups}

The interviews revealed that none of the surveyed Islamic banks have received any financing application from FinTech start-ups in Oman. In this context, interviewee $\mathrm{C}$ provided a typical response:

Unfortunately, our bank only finances "big" companies that are well known in the market and have the necessary financial requirements

This might be explained by the relatively restrictive nature of IFIs with regards to financing start-ups in general, and particularly in technology-related businesses [31] [32] which acts as the main barrier to their growth [33]. 
Interviewee B added that:

It is generally difficult for these firms to obtain financing from both Islamic and conventional banks because of the unavailability of financial statements reflecting their current and potential financial situation.

In fact, the lack of credit history and credible reputation distinguishes start-ups from established firms, creating a disadvantage for the former when it comes to the issue of funding [34]. In addition, [35] found that banks only consider financing start-ups that are at least five years old and those that can offer working prototypes.

Specifically, [18] found that FinTech in most emerging countries, including MENA countries is still under-developed. More particularly, [14] found that FinTech start-up formations are rare in countries where the latest technologies are not readily available, capital markets are not well-developed, and people do not have sufficient mobile telephone subscriptions. In addition, [34] found that the absence of financial liberalization greatly affects the overall financial investment in FinTech start-ups. Hence, these aspects have to be developed to enhance the FinTech industry in Oman. This also indicates that based on these characteristics, FinTech has a great potential for growth in Oman.

Nevertheless, the absence of Islamic financing applications from FinTech start-ups can also be due to the lack of interest of the Omani businesses in FinTech until now, as some Islamic banks might be willing to finance Fintech start-ups if they satisfy some requirements by these banks. In support of this view, interviewee F from another bank noted that:

Our bank is opened to financing this kind of businesses, and supports them continuously especially in the current era where creating jobs becomes a must in Oman...And this is what should be done by all the Omani Islamic banks

Furthermore, Islamic financing arrangements usually require a comprehensive and convincing documentation, including feasibility study, internal policies, Board of Directors approval and project's meeting the relevant credit risk's requirements [36]. In this regard, interviewee $\mathrm{G}$ mentioned that:

A major requirement for us is the experience of the management and executives of the start-up company, and their specialisation in its field of business...the high expected rate of return is also important...the working capital and budget management style is also important for us

Interviewee $\mathrm{C}$ added that a valuable collateral/Rahn is also required as it gives an additional credit to start-up companies that usually do not have a known history in business. In the same context, interviewee E added that the start-ups are required to submit a comprehensive and detailed market feasibility study performed by a specialized firm.

These requirements are even stricter because of the relatively higher level of perceived risk involved with these types of businesses. In fact, the FinTech start-ups usually create new and innovative products or services "under conditions of extreme uncertainty" that are mostly technology related [37]. Furthermore, they apply innovative business models that are yet to be tested [38]. Because of these conditions, the FinTech start-ups usually have an unstable and volatile growth rate that makes it even more difficult to predict their future growth [38]. In this regard, interviewee E stated that:

FinTech start-ups have a very high possibility of failure and bankruptcy since the area of FinTech itself is still new and continuously expanding and also because of high regional competition

This view was also supported by interviewee B who claimed that:

There is a high default risk in the case of FinTech start-ups due to the lack of market experience, the continuous development in this area, and the regional and global competition

This might partially explain the rationale for Islamic banks in Oman to prefer short term financing on a wide range of financing options to start-ups. This includes merchandise Murabahah, Musharakah, Ijarah Muntahiyah Bi Tamleek, and Wakalah contracts in some cases. In this regard, interviewee A noted that:

We prefer to provide financing through Musharakah but for a maximum of three years

At the same time, the interviewees stated that the business start-ups, in general, prefer long term financing as it gives them more flexibility and margin of performance and development. Interviewee E noted here that:

Our customers usually prefer long term financing through instruments like Murabahah as they perceive it to be less costly and more flexible

Even though the FinTech start-ups are generally associated with relatively high levels of uncertainty and risk, they are also characterised by one of the greatest potentials for growth and sustainability across industries [39] [40]. Hence, if these businesses are properly and accurately analysed and evaluated by IFIs, they can form a significant source of sustainable income for them and a source of advanced financial technology as well.

\section{Future of FinTech in Islamic Finance}

Finally, with regards to the future role that can be played by FinTech in developing Islamic finance industry in Oman, the interviewees were generally 
supportive and highly optimistic. Interviewee A for instance stated that:

Oman is a majority Muslim country and the preference of Islamic banks over conventional banks has been obvious since the introduction of Islamic banks. The involvement and contribution of FinTech to the Islamic finance industry will make it much better in the future

In the same context, interviewee $\mathrm{C}$ noted that:

FinTech tools are still relatively new in Oman, but they have a great potential to expand in the future and also contribute to the expansion and development of Islamic finance services in the country

Particularly, Interviewee F added that:

In the future, these start-ups will have more market experience which means their level of risk will be reduced and as a result they will easily obtain financing and have a variety of financing options especially from Islamic banks

Hence, it is imperative for Islamic banks to be actively involved in the Fintech industry to gain practical experience of its developments and challenges [15]. This will certainly give an advantage to Islamic banks in Oman compared to the conventional banks especially in the midst of the strong competition between both the systems [13]. In addition, the IFIs should apply different criteria in financing FinTech start-ups compared to the traditional business start-ups. As discussed above, FinTech business is a kind of financial services business using the technology to ease and serve wider customers [15]. The Islamic banks should consider financing FinTech start-ups as one of the means in achieving the five Maqasid of Shari'ah (Shari'ah objectives).

\section{DISCUSSION AND CONCLUSIONS}

The objective of the study was mainly to shed light on the current state and future prospects of FinTech in Oman, with special emphasis on its potential contribution to the Islamic finance area. The findings revealed that the FinTech industry in Oman is still operating underpotential. This might be due to the general lack of interest in this area by the Omani start-up businesses. The findings also showed that the start-ups in Oman prefer long term financial schemes, while the IFIs generally prefer short term financing on Musharakah and Ijarah contracts. Finally, the findings showed that the IFIs in Oman are optimistic regarding the prospects of growth and success of FinTech in Oman.

In light of the above findings, it becomes imperative for IFIs in Oman to comprehensively adjust their operating procedures and policies to provide more flexibility in financing start-ups, especially in the FinTech field. This endeavour will not only provide a significant source of income to these institutions, but will also continuously support them and supply the latest FinTech tools to them, which will make them more competitive not only local but regionally, and which can also lead to the economic growth of industries as well as the economy as a whole. Particularly, the IFIs are recommended to take actions that will as much as possible reduce any gaps between what FinTech start-ups expect and what the IFIs offer to them, either in terms of financing, or the conditions and requirements necessary to provide funding.

Finally, the current study has a number of limitations that should be considered by future studies. Firstly, the current study focused only on the Omani context, hence the findings cannot be generalized to regional settings. Secondly, the study relied solely on qualitative research methods in form of an interview with eight respondents from IFIs in Oman. In this regard, the future studies are recommended to use mixed methods approach to triangulate and strengthen the qualitative findings with quantitative findings.

\section{REFERENCES}

[1] Alt, R., Beck, R., \& Smits, M.T. FinTech and the transformation of the financial industry. Electronic Markets, 28(3), 235-243. 2018

[2] Philippon, T. The Fintech opportunity. BIS Working Paper No. 655. Bank for International Settlements, Basel. 2017.

[3] Prawirasasra, K.P. Financial technology in Indonesia: Disruptive or collaborative? Reports of Economics and Finance, 4(2), 83-90. 2018

[4] Leong, C., Tan, B., Xiao, X., Tan., F.T.C., \& Sun, Y. 2017. Nurturing a FinTech ecosystem: The case of a youth microloan startup in China. International Journal of Information Management, 37(1), 92-97. 2017.

[5] Li, Y., Spigt, R., \& Swinkels, L. The impact of FinTech start-ups on incumbent retail banks' share prices. Financial Innovation, 26(3), 1-16. 2017.

[6] Echchabi, A., \& Azouzi, D. Oil price fluctuations and stock market movements: An application in Oman. Journal of Asian Finance Economics and Business, 4(2), 19-23. 2017.

[7] ACCA. FinTech transforming finance. ACCA, London. 2016.

[8] Joseph, N., \& Hemalatha, N. A survey on the implementation of Fintech in different industries. International Journal of Latest Trends in Engineering and Technology, 6(1), 461-465. 2016.

[9] Li, Y., Spigt, R., \& Swinkels, L. The impact of FinTech start-ups on incumbent retail banks' share prices. Financial Innovation, 26(3), 1-16. 2017.

[10] Joseph, J., \& Varghese, T. Role of financial inclusion in the development of Indian economy. Journal of Economics and Sustainable Development, 5(11), 6-11. 2014

[11] Guild, J. Fintech and the Future of Finance. Asian Journal of Public Affairs, 10(1), 1-14. 2017. 
[12] Yang, Y., Hsueh, H., Huang, M., Cho, T., \& Kishi, Y. Effect of Fintech on the Productivity in the Taiwan Banking Industry. International Journal of eEducation, e-Business, e-Management and eLearning, 7(4), 255-263. 2017.

[13] Gillet, K. "Fintech and Islamic finance: a mutually beneficial match?". https://www.thebanker.com/Markets/IslamicFinance/Fintech-and-Islamic-finance-a-mutuallybeneficial-match?ct=true. Accessed online on December $14^{\text {th }} .2017$.

[14] Haddad, C., \& Hornuf, L. The emergence of the global fintech market: Economic and technological determinants. Working paper in SSRN Electronic journal. DOI: 10.2139/ssrn.2830124. 2016.

[15] Wintermeyer L., \& Basit, A.H. "The Future of Islamic FinTech Is Bright”. https://www.forbes.com/sites/lawrencewintermeyer/2 017/12/08/the-future-of-islamic-fintech-isbright/\#17cd3a6565fa, Accessed online on December $14^{\text {th }} .2017$.

[16] Wamda \& Payfort. "FinTech in MENA: Unbundling the financial services industry". https://www.difc.ae/files/3614/9734/3956/fintechmena-unbundling-financial-services-industry.pdf. Accessed online on December 14 ${ }^{\text {th }} .2017$.

[17] BNM. Islamic finance technology and innovation. BNM, Malaysia. 2016.

[18] Zalan, T., \& Toufaily, E. The promise of fintech in emerging markets: Not as disruptive. Contemporary Economics, 11(4), 415-430. 2017.

[19] Frame, W.S.,Wall, L., \& White, L.J. Technological Change and Financial Innovation in Banking: Some Implications for Fintech. Working Paper wp2018-11. Federal Reserve Bank of Atlanta, Atlanta. 2018.

[20] Arner, D.W., Barberis, J., \& Buckley, R.P. The evolution of Fintech: A new post-crisis paradigm. Georgetown Journal of International Law, 47(1), 1271-1315. 2015.

[21] Tasca, P., Aste, T., Pelizzon, L., \& Perony, N. Banking Beyond Banks and Money. Springer International Publishing: New York. 2016.

[22] Lee, I., \& Shin, Y.J. Fintech: Ecosystem, business models, investment decisions, and challenges. Business Horizons, 61(1), 35-46. 2018.

[23] Wahjono, S.I., Marina, A., Widayat, A., \& Nasir, M. Islamic crowdfunding: A comparative analytical study on Halal financing. Global Conference on Business and Finance, January 2nd-5th, The Institute of Business and Finance Research, Las Vegas. 2017.

[24] Wamda \& Payfort "FinTech in MENA: Unbundling the financial services industry". https://www.difc.ae/files/3614/9734/3956/fintechmena-unbundling-financial-services-industry.pdf. Accessed online on December 14 $4^{\text {th }} .2017$.

[25] Kolesova, I.V., \& Girzheva, Y.S. Impact of Financial Technologies on the Banking Sector. Institute International Scientific and Research Conference: FinTech and RegTech: Possibilities, Threats and Risks of Financial Technologies. Russian Academy of
Sciences, pages 215-220. DOI 10.18502/kss.v3i2.1545. 2017.

[26] Fenwick, M., Mccahery, J.A., \& Vermeulen, E.P.M. Fintech and the Financing of Entrepreneurs: From Crowdfunding to Marketplace Lending. TILEC Discussion Paper No. DP 2017-025. Tilburg University, Netherlands. 2017.

[27] Yilmaz, K. Comparison of Quantitative and Qualitative Research Traditions: epistemological, theoretical, and methodological differences. European Journal of Education, 48(2), 311-325. 2013.

[28] Mohajan, H. Qualitative research methodology in social sciences and related subjects. Journal of Economic Development, Environment and People, 7(1), 23-48. 2018.

[29] Polit, D., Beck, C., \& Hungler, B. Essentials of nursing research: Methods, appraisal and utilisation. Narberth, PA: Lippincott. 2001.

[30] Alexis, O., \& Vydelingum, V. Migrating registered nurses in the UK: Black and minority ethnic overseas nurses' perspective. International Journal of Health Care Quality Assurance, 20(5), 441-452. 2007.

[31] Hamouri, B.M., Hamouri, Q., \& Radaydeh, M. The impact of Islamic financing and conventional financing on companies' performance (a comparative study of industrial companies listed on the Amman stock exchange). International Journal of Business and Social Science, 5(7), 58-72. 2014.

[32] Shaban, M., Duygun, M. \& Fry, J. SME's lending and Islamic finance: Is it a "win-win" situation? Economic Modelling, 55(1), 1-5 2016.

[33] Tariq, T. Start-up financing. First IBA Thesis Conference, June 27th, The Netherlands. 2013.

[34] Korosteleva, J., \& Mickiewics, T. Start-up financing in the age of globalization. Economics Working Paper No. 96, UCL School of Slavonic and East European Studies, London. 2010.

[35] Semerikova, E. Factors attracting banking investment into fintech start-ups: Russian context. Proceedings of the Second American Academic Research Conference on Global Business, Economics, Finance and Social Sciences, April 28-30, New York, USA. 2017.

[36] Salehuddin, S., \& Saiti, B. Musharakah tijarah crossborder financing: Concept, structure and salient features. International Journal of Islamic Economics and Financial Studies, 2(3), 1-25. 2016.

[37] Calopa, M.K., Horvat, J., \& Lalic, M. Analysis of financing sources for start-up companies. Management, 19(2), 1944. 2014.

[38] Goudriaan, T. Startups and funding: A comparative analysis of Amsterdam and Stockholm. Master thesis. Utrecht University, Netherlands. 2016.

[39] Balboni, B., Bortoluzzi, G., Tivan, M., Tracogna, A., $\&$ Venier, F. The growth drivers of start-up firms and business modelling: a first step toward a desirable convergence. Management, 9(2), 131-154. 2014.

[40] Blagoev, D., Kopeva, D., Sterev, N., Jordanova, Z., \& Bojilova, V. Start-up for sustainable growth in Bulgaria. Trakia Journal of Sciences, 13(1), 318-322. 201 